\title{
Serum Factor in Cystic Fibrosis: Correlation with Clinical Parameters
}

\author{
E. CZEGLEDY NAGY, S. KHAN, AND J. M. STURGESS
}

Departments of Pathology and Paediatrics, The Hospital for Sick Children, Toronto, Canada

\begin{abstract}
Summary
The relationship between the activity of the cystic fibrosis serum ciliary dyskinesia factor, detected by the rabbit tracheal bioassay, and clinical status of the patient has been investigated in children, 1-24 years old, with cystic fibrosis. No significant correlation was found between the amount of serum factor activity and age, clinical status assessed by the Schwachman score, pulmonary function (vital capacity, functional residual capacity, total lung capacity, residual volume, maximum breathing capacity, maximal midinspiratory flow, and maximal midexpiratory flow) or blood gas levels $\left(\mathrm{pCO}_{2}, \mathrm{pO}_{2}\right)$. The activity showed no significant relationship to serum galactosyltransferase activity in children with cystic fibrosis.
\end{abstract}

\section{Speculation}

The substance responsible for the ciliary dyskinesia serum factor activity detected in children with cystic fibrosis may not be directly involved in the clinical syndrome or in its pathophysiology.

In 1967, Spock et al. (16) demonstrated a factor in serum of patients with cystic fibrosis which was not present in normal children. A similar factor or factors have since been demonstrated in serum, saliva $(7,10)$, urine, and cultured skin fibroblasts (5), and lymphoblasts (8) from cystic fibrosis subjects, as well as in obligate heterozygotes for this disease. The factor(s) are low molecular weight, cationic peptides $(6,19)$ which influence ciliary activity (1) and promote mucus secretion $(9,17)$ in the rabbit trachea and the oyster gill (4). Mucociliary transport has been studied in cystic fibrosis and has been shown to be markedly reduced in comparison with the normal subjects $(21,22)$. It has not been established yet whether the serum factor influences mucociliary activity in the human lung (20). Despite this fact, there has been considerable speculation that the factor is closely related to the basic defect in this disease and that it may have a role in the pathogenesis of lung disease in cystic fibrosis.

To evaluate the possible relationship between the serum factor and clinical aspects of lung disease in cystic fibrosis, the activity of the factor was assayed in patients and compared with various clinical pulmonary function parameters.

The activity of serum factors in the bioassay has been compared with the levels of serum galactosyltransferase. Elevated levels of glycosyltransferase enzymes, which catalyze the transfer of carbohydrates onto glycoproteins, have been observed in lung microsomes (11) and in cultured skin fibroblasts (13). The enhancement of enzyme activity has been attributed to a basic disturbance in the regulation of glycosyltransferases (11) and to a secondary phenomenon resulting from their interaction with circulating basic polypeptides in cystic fibrosis (13). In this study, no significant relationship was observed between the level of serum factor activity and serum galactosyltransferase.

\section{MATERIALS AND METHODS}

Blood samples collected for routine investigation from 46 different patients with cystic fibrosis, attending the cystic fibrosis clinic at The Hor-ita: for Sick Children were used in this study. Serum was separated and stored at $-70^{\circ} \mathrm{C}$. All samples were assayed within 1 week of collection. The children were in the age range of 1-24 yr. Clinical data (Table 1), pulmonary function, and blood gas determinations were recorded at the time of evaluation of serum in the bioassay and for glycosyltransferase activity. The following pulmonary function parameters were measured: vital capacity, functional residual capacity (FRC), total lung capacity (TLC), residual volume (RV), maximum breathing capacity (MBC), maximal midinspiratory flow (MMIF) and maximal midexpiratory flow (MMEF). The methods for examining these parameters have been described previously (19) and values were calculated as percents of values predicted for normal children of that age.

Galactosyltransferase activity was determined in serum as described previously (14).

The rabbit tracheal assay for cystic fibrosis serum was carried out as described in detail previously (1). Briefly, explants of rabbit tracheal epithelium were maintained in organotypic culture for 24-48 hr. Serum samples were then assayed by observation of epithelial surfaces. The activity of serum factor was recorded from the 1) discharge of material from the explant surface and 2) ciliary dyskinesia at different time intervals up to $30 \mathrm{~min}$. The response was calculated as earliest response time for each parameter and as a numerical index of the rate of response (grade of intensity of response, $1-4$, plotted against unit time). The results for seven patients compared in this way are summarized in Table 2.

Duplicate samples collected from the same patient, gave similar activity in the assay, as judged by the earliest response time. These activity levels were similar in one patient for periods up to $1 \mathrm{yr}$.

\section{RESULTS}

\section{SERUM FACTOR ACTIVITY}

Serum samples were grouped according to the earliest response time in the rabbit tracheal assay. Six groups were defined: 1-5 min, (I); 6-10 min, (II); 11-15 min, (III); 16-20 min, (IV); 21-25 $\mathrm{min},(\mathrm{V})$; and $26-30 \mathrm{~min},(\mathrm{VI})$.

Sera from most patients $(n=39)$ produced a response within 15 min incubation; one patient showed a response in $20 \mathrm{~min}$ and one at $25 \mathrm{~min}$; four patients' sera showed minimal response, detected only at $30 \mathrm{~min}$. Sera from normal children produced no response within $30 \mathrm{~min}$ assay.

\section{CORRELATION WITH CLINICAL DATA}

Serum activity was compared with age, Schwachman score, respiratory function (MMIF, MMEF, MBC, TLC, RV/TLC and $\mathrm{FRC} / \mathrm{TLC}$ ) blood gases ( $\mathrm{pCO}_{2}$ and $\mathrm{pO}_{2}$ ), and galactosyltransferase activity (an index of plasma glycoprotein secretion). The results are summarized in Table 3. Data from patients showing response after $16 \mathrm{~min}$ were grouped together to allow statistical analysis. 
Table 1. Clinical data

\begin{tabular}{|c|c|c|c|c|c|c|c|c|}
\hline Patient & Sex & Age & Schwachman score & Clinical G I & Symptoms (Lung) & Sputum & Drugs $^{1}$ & \\
\hline \multicolumn{9}{|l|}{ Group I } \\
\hline S.T. & $\mathbf{F}$ & 10 & 75 & + & + & + & $\mathrm{Ce}, \mathrm{Al}, \mathrm{In}$ & \\
\hline R.B. & M & 12 & 80 & + & + & + & $\mathrm{Ce}, \mathrm{Al}, \mathrm{In}$ & \\
\hline $\mathbf{J} \cdot \mathbf{A}:$ & $\mathrm{F}$ & 15 & 80 & - & + & ++ & $\mathrm{C}, \mathrm{Is}$ & \\
\hline J,B. & M & 18 & 70 & + & $\neq$ & + & $\mathrm{Ce}, \mathrm{Al}$, In & \\
\hline P.B. & $\mathrm{F}$ & 18 & 40 & + & $\neq$ & $\neq$ & $\mathrm{Ce}_{1} \mathrm{Al}, \mathrm{In}$ & \\
\hline J,B. & $\mathbf{F}$ & 19 & 45 & + & + & $\neq$ & $\mathrm{L}, \mathrm{T}, \mathrm{Al}, \mathrm{In}$ & \\
\hline $\mathbf{J}, \mathbf{S}$ & F & 19 & 85 & $=$ & $\neq$ & $\neq$ & $\mathrm{L}, \mathrm{T}, \mathrm{Al}$ & \\
\hline S.P. & $\mathrm{P}$ & 24 & 45 & + & $\neq$ & $\neq \neq$ & $\mathrm{L}, \mathrm{S}, \mathrm{In}$ & \\
\hline \multicolumn{9}{|l|}{ Group II } \\
\hline J,O, & $\mathbf{M}$ & 5 & 60 & $\neq$ & $\neq$ & $\neq$ & $\mathrm{Ce}, \mathrm{Al}$, In & \\
\hline R.B. & $\mathbf{M}$ & 10 & 75 & $\neq$ & $\neq$ & $\neq$ & $\mathrm{Ce}, \mathrm{Is}, \mathrm{In}$ & \\
\hline $\mathrm{L}, \mathrm{B}$ & $\mathrm{F}$ & 11 & 75 & + & $\neq$ & $\neq$ & $\mathrm{Ce}, \mathrm{Al}, \mathrm{In}$ & \\
\hline R.B. & $\mathbf{M}$ & 11 & 70 & $\neq$ & $\neq$ & $\neq$ & $\mathrm{Ce}, \mathrm{Al}, \mathrm{In}$ & \\
\hline K.C. & $\mathbf{M}$ & 11 & 95 & + & $\neq$ & $\neq$ & $\mathrm{L}, \mathrm{Al}, \mathrm{In}$ & \\
\hline K.V. & M & 13 & 85 & $\neq$ & $\neq$ & $\neq$ & $\mathrm{Ce}, \mathrm{O}, \mathrm{Am}, \mathrm{Al}, \mathrm{In}$ & \\
\hline R.H. & M & 14 & 70 & $\neq$ & $\neq$ & ++ & $\mathrm{Ce}, \mathrm{Al}, \mathrm{In}$ & \\
\hline$L, K$ & $\mathrm{~F}$ & 14 & 95 & + & $=$ & $=$ & $0, \mathrm{Am}$ & \\
\hline J.F & $\mathrm{F}$ & 15 & 75 & + & $\neq$ & + & $\mathrm{Ce}, \mathrm{Al}$ & \\
\hline J.L. & $\mathrm{M}$ & 15 & 80 & + & $\neq$ & ++ & $\mathrm{Ce}, \mathrm{S}$, In & \\
\hline J,M. & $\mathrm{M}$ & 15 & 40 & $\neq$ & $\neq$ & $\neq$ & 0, Is & \\
\hline D.M. & $\mathbf{M}$ & 16 & 65 & + & $\neq$ & $\neq$ & $\mathrm{L}, \mathrm{Al}$, In & \\
\hline H.C. & $\mathbf{M}$ & 17 & 75 & $\neq$ & $\neq$ & + & Ce, Al, In & \\
\hline $\mathbf{S}, \mathbf{G}$ & M & 17 & 90 & + & $\neq$ & $\neq$ & $\mathrm{L}, \mathrm{Is}, \mathrm{In}$ & \\
\hline M.L. & $\mathrm{F}$ & 17 & 50 & + & $\neq$ & $\neq$ & $\mathrm{L}, \mathrm{Al}$ & \\
\hline P.L. & M & 17 & 90 & $\neq$ & + & $\neq$ & $\mathrm{Ce}, \mathrm{Al}$, In & \\
\hline K.L. & $\mathbf{M}$ & 17 & 85 & $\neq$ & + & $\neq$ & L & \\
\hline $\mathrm{J}, \mathrm{P}$ & $\mathbf{M}$ & 17 & 65 & $\neq$ & $\neq$ & $\neq$ & $\mathrm{Ce}, \mathrm{Al}, \mathrm{In}$ & \\
\hline A.C. & $\mathbf{M}$ & 18 & 80 & $\neq$ & $\neq$ & $\neq$ & $\mathrm{Ce}, \mathrm{Al}$, In & \\
\hline K.J, & M & 18 & 65 & $\neq$ & $\neq$ & $\neq$ & $\mathrm{L}, \mathrm{Al}$ & \\
\hline B.S. & $\mathrm{F}$ & 20 & 45 & $\neq$ & $\neq$ & $\neq \neq$ & $\mathrm{Ce}, \mathrm{Al}$, In & \\
\hline L.M. & $\mathrm{F}$ & 21 & 45 & $\neq$ & $\neq$ & $\neq+$ & $\mathrm{Ce}, \mathrm{Al}$, In & \\
\hline \multicolumn{9}{|l|}{ Group III } \\
\hline J.C. & $\mathbf{M}$ & 1 & 90 & $\neq$ & $\neq$ & $=$ & $\mathrm{Ce}, \mathrm{Al}, \mathrm{In}$ & \\
\hline J,P, & F & 11 & 80 & + & + & $\neq$ & $\mathrm{Ce}, \mathrm{Al}, \mathrm{In}$ & \\
\hline D.R. & M & 11 & 75 & $\neq$ & $\neq$ & $\neq$ & Cal, Tri, Al, In & \\
\hline N.J. & M & 12 & 90 & + & $\neq$ & $\neq$ & $\mathrm{L}$ Is & \\
\hline C.J. & $\mathrm{F}$ & 13 & 93 & + & $\neq$ & + & $\mathrm{Ce}, \mathrm{Al}$, In & \\
\hline $\mathrm{D}, \mathrm{H}$ & $\mathrm{F}$ & 15 & 45 & + & $\neq$ & $\neq+$ & $\mathrm{L}, \mathrm{Al}$ & \\
\hline B.M. & M & 18 & 70 & + & $\neq$ & $\neq$ & $\mathrm{Ce}, \mathrm{S}$, In & \\
\hline R.A. & $\mathbf{M}$ & 24 & 80 & $\neq$ & $\neq$ & $\neq$ & $\mathrm{L}, \mathrm{Is}$, In & \\
\hline \multicolumn{9}{|l|}{ Group IV } \\
\hline S.M. & $\mathrm{F}$ & 13 & 50 & $\neq$ & $\neq$ & $\neq$ & $\mathrm{Ce}, \mathrm{S}$ & \\
\hline $\mathbf{A}, \mathbf{R}$. & $\mathbf{M}$ & 14 & 80 & + & $\neq$ & $\neq$ & $\mathrm{Ce}, \mathrm{Al}$ & \\
\hline $\mathbf{P}, \mathbf{S}$, & $\mathrm{P}$ & 14 & 60 & $\neq$ & $\neq$ & $\neq$ & $\mathrm{Ce}, \mathrm{Al}$, In & \\
\hline C.N. & $\mathrm{P}$ & 16 & 30 & $\neq$ & $\neq$ & $\neq+$ & $\mathbf{L}, \mathbf{S}$ & \\
\hline S.S. & $\mathrm{F}$ & 16 & 75 & $\neq$ & $\neq$ & + & $\mathrm{L}, \mathrm{Al}, \mathrm{In}$ & \\
\hline B.S. & $\mathbf{F}$ & 19 & 60 & + & $\neq$ & + & $\mathrm{M}, \mathrm{Car}, \mathrm{To}, \mathrm{Al}$, In & \\
\hline A.W, & $\mathrm{M}$ & 19 & 80 & + & + & + & $\mathrm{Ce}, \mathrm{Al}$, In & \\
\hline
\end{tabular}

'Abbreviations for drugs; A=Alupent, Am=Ampicillin, C-Cloxillin, Ce-Ceporan, Car=Carbenicillin, Cal-Calbemin, In-Intal, Is=Isuprel, L=Lincocin, $\mathrm{M}=$ Methacillin, $\mathrm{O}=$ Orbenin, $\mathrm{S}=$ Salbutamol, T=Tetracycline, Tri=Triamcinolone, To=Tobramycin.

\section{AGE}

Within groups I-III, responding within 15 min assay, there appeared to be a trend towards older patients giving higher serum factor activity. This was not statistically significant.

\section{SCHWACHMAN SCORE}

An improvement in the average Schwachman score was ob= served between patients in group I, with higher serum factor activity, and group II, with lower activity. The average Schwach. man score for group IV who showed minimal serum factor activity, was low and the ranges of individual Schwachman score in each group (Table 1) was similar. The apparent trend was not statisti= cally significant.

\section{PULMONARY FUNCTION AND BLOOD GASES}

Trends indicating decreased MMIF and increased TLC with greater serum activity were not statistically significant. Similar trends towards increased MBC and RV/TLC were not significant.

Blood gas levels showed no correlation with levels of serum activity. 


\section{GALACTOSYLTRANSFERASE}

Serum galactosyltransferase activity was significantly lower in all cystic fibrosis patients than the levels reported for age-matched normal children (15). In comparison with serum factor activity, there was an increase in the mean values of galactosyltransferase activity in groups I-III; this trend was not statistically significant.

\section{DISCUSSION}

Recently, there has been considerable speculation as to the role of serum factors in the pathogenesis of cystic fibrosis, based on observations in rabbit and oyster gill tissues. However, it has been proposed as a contributory factor in the human respiratory tract, influencing mucociliary clearance (14). Araki et al. (2) have measured the electrical properties of rat jejunum in the presence of cystic fibrosis serum and conclude that active factors in cystic fibrosis serum may inhibit active sodium transport as well as passive permeability to ions. These measurements confirmed the earlier suggestion that the cystic fibrosis factor may be involved in the inhibition of sodium transport (12).

The clinical implications of the serum factor response have been questioned recently, by Warwick and Shapiro (18) who observed that more than $90 \%$ replacement of plasma volume in two cystic

Table 2. Comparison of response time and index of response rate of different patients ${ }^{1}$

\begin{tabular}{ccccc}
\hline \multicolumn{2}{c}{ Discharge } & & \multicolumn{2}{c}{ Ciliary Dyskinesia } \\
\cline { 1 - 2 } \cline { 5 - 5 } $\begin{array}{c}\text { Earliest } \\
\text { response } \\
\text { (min) }\end{array}$ & $\begin{array}{c}\text { Index } \\
\text { of Rate }\end{array}$ & & $\begin{array}{c}\text { Earliest } \\
\text { Response } \\
\text { (min) }\end{array}$ & $\begin{array}{c}\text { Index } \\
\text { of Rate }\end{array}$ \\
\hline 5 & 1.0 & & 10 & 0.38 \\
5 & 2.0 & & 10 & 0.8 \\
10 & 0.9 & & 10 & 0.6 \\
10 & 0.9 & & 10 & 0.14 \\
15 & 0.3 & & 20 & 0.17 \\
15 & 0.3 & & 25 & 0.17 \\
15 & 0.23 & & 25 & 0.15 \\
\hline
\end{tabular}

'The activity of serum factors in the rabbit tracheal assay was recorded as (1) earliest response time and as (2) a numerical index representing the rate of response derived from a plot of response in the assay vs. time. fibrosis patients caused no change in their sweat chloride levels. From this evidence, they have suggested that the cystic fibrosis factor in serum may not necessarily be involved in the clinical syndrome or its physiologic antecedents. A similar study was carried out in this hospital with six cystic fibrosis patients who received infusions of fresh frozen plasma. No change was detected in either the sweat chloride or the serum factor activity in five of these patients while one showed slight lowering of both sweat chloride and serum factor activity (authors' unpublished data). This evidence supports the fact that level of activity detected in the bioassay of cystic fibrosis serum does not, alone, reflect the physiologic or pathologic aspects of the disease on a direct basis. The presence of circulating cationic substances in patients with cystic fibrosis and their relevance to pulmonary clearance remains unclear. The fact that the activity of the serum factor bears no relationship to the degree of pulmonary involvement in individuals with cystic fibrosis and that similar active factors can be detected in asymptomatic carriers, who are obligate heterozygotes for this disease, suggests that the factors are not directly responsible for the pulmonary pathophysiology. One possibility which should be considered is that the presence of such circulating cationic peptides may contribute to the pathogenesis of lung disease in the presence of other predisposing factors such as infection.

The clinical status and pulmonary function data show no significant relationship to the activity of serum factor in patients with cystic fibrosis. The lack of correlation indicates that this factor may not play a major role in the progression of lung disease, at least within the sensitivity of the present assay procedure. These results reflect the findings in a smaller group of patients in which there was a correlation between serum factor activity and mucociliary transport rates in the trachea of children with cystic fibrosis (22). In that study, the tracheal clearance rates were faster in those patients with higher serum factor activity.

In slower reacting sera, group VI, most sera were from inpatients admitted to hospital with hepatomegaly and all had low plasma protein levels. The sera in this group showed a minimal response in the assay. This may indicate that certain protein components of serum are important in the activity determined in the assay system. Plasma protein levels were not available for all patients in groups I-III to allow direct comparison of this parameter.

Hyperactivity of glycosyltransferases $(11,13)$ has been proposed as a basic disturbance in cystic fibrosis. Rao et al. (13) have

Table 3. Correlation of response in rabbit tracheal bioassay with clinical parameters ${ }^{1}$ for $C F$ patients

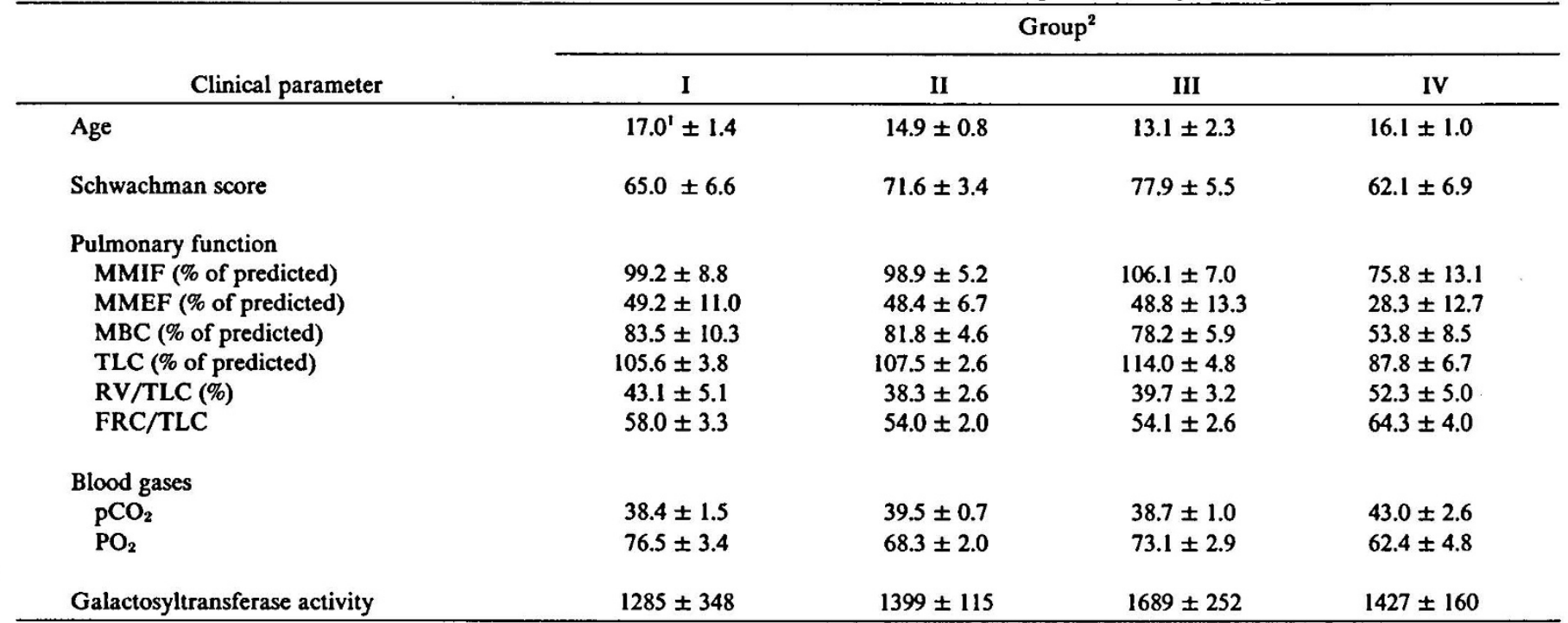

' Values represent the mean \pm SE for each group. The serum factor activity is assessed from the time when the first changes are detected in the assay i.e., the earliest response time. For all sera, the earliest response represents discharge from the explant surface rather than ciliary dyskinesia. Similar data are obtained in comparing ciliary dyskinesia, but response times are slower.

${ }^{2}$ Groups are defined according to the earliest response time in the assay, as follows: I, 1-5 min; II, 6-10 $\mathrm{min}$; III, 11-15 min; IV, > $20 \mathrm{~min}$. 
suggested that the enhancement of enzyme activity, observed in cultured skin fibroblasts may be secondary to their interaction with basic polypeptides. They may account for the elevated glycosyltransferase activity reported in lung microsomes (11) since these enzymes are activated by cationic substances such as polyamines (3). The lack of activation which is observed in the serum galactosyltransferase enzyme does not support this hypothesis. However, it is possible that the serum enzyme may behave differently from the intracellular membrane-bound glycosyltransferases in response to cationic substances.

\section{REFERENCES AND NOTES}

1. Adshead, P. C., Martinez, J. R., Kilburn, K. H., Hess, R. A.: Ciliary inhibition and axonemal microtubule alterations in freshwater mussels. Ann. N. Y. Acad. Sci., 253: 192 (1975).

2. Araki, H., Field, M. and Schwachman, H.: A new assay for cystic fibrosis factor: effects of sera from patients with cystic fibrosis in the in vitro electrical properties of rat jejunum. Pediatr. Res., 9: 932 (1975).

3. Baker, A. P., and Chakrin, L. W. (1977) Glycosyltransferases and hypersecretion of respiratory mucus. In: F. Falkner: Mucus Secretions and Cystic Fibrosis. Modern Problems in Paediatrics. Vol. 19, p. 99-109, (Karger, Basel) 1977.

4. Baur, P. S., Brinkley, B. R., and Bowman, B. H.: Effects of cystic fibrosis serum ciliary inhibitor on oyster gill ultrastructure: analysis by scanning and transmission electron microscopy. Tex. Rep. Biol. Med., 34: 155 (1976).

5. Beratis, N. G., Conover, J. H., Conod, E. J., Bonforte, R. J., and Hirschhorn, K. Studies on ciliary dyskinesia factor in cystic fibrosis III. Skin fibroblasts and cultured amniotic fluid cells. Pediatr. Res., 7: 958 (1973).

6. Bowman, B. H., Lankford, B. J., Fuller, G. M., Carson, S. D., Kurosky, A., and Barnett, D. R.: Cystic fibrosis: the ciliary inhibitor is a small polypeptide associated with immunoglobulin G. Biochem. Biophys. Res. Commun., 64: 1310 (1975).

7. Bowman, B. H., Lockhart, L. H., McCombs, M. L.: Oyster ciliary inhibition by cystic fibrosis factor. Science, 164: 325 (1969).

8. Conover, J. H., Beratis, N. G., Conod, E. J., Ainbender, E., and Hirschhorn, K.: Studies on ciliary dyskinesia factor in cystic fibrosis. II Short term leukocyte cultures and long term lymphoid lines. Pediatr. Res., 7: 224 (1973).

9. Czegledy-Nagy, E., Sturgess, J. M.: Cystic fibrosis: effect of serum factor on mucus secretion. Lab. Invest., 35: 588 (1976).
10. Dogget, R. G., and Harrison, G. M.: Cystic fibrosis: in vitro reversal of the ciliostatic character of serum and salivary secretions by heparin. Nature, 243: 251 (1973).

11. Louisot, P., Levrat, C., and Gilly, R.: A new pathogenic hypothesis for cystic fibrosis: hyperactivity of glycosyltransferases at microsomic levels. Clin. Chim. Acta, 48: 373 (1973).

12. Mangos, J. A., and McSherry, N. R.: Studies on the mechanisms of inhibition of sodium transport in cystic fibrosis. Pediatr. Res., 2: 378 (1968).

13. Rao, G. J. S., Spells, G., and Nadler, H. L.: Enhanced UDP-galactose: glycoprotein galactosyltransferase activity in cultured skin fibroblasts from patients with cystic fibrosis and its possible relationship to the pathogenesis of the disease. Pediatr. Res., 11: 981 (1977).

14. Sanchis, J., Dolovich, M., Rossman, C., Wilson, W., Newhouse, M.: Pulmonary mucociliary clearance in cystic fibrosis. N. Engl. J. Med., 289: 749 (1974).

15. Singer, L., Crozier, D., and Moscarello, M. A.: The levels of galactosyltransferase activity in sera from normal children and patients with cystic fibrosis. Clin. Biochem., 7: 146 (1974).

16. Spock, A., Heick, H. M. C., Cress, H., Logan, W. S.: Abnormal serum factor in patients with cystic fibrosis of the pancreas. Pediatr. Res., I: 173 (1967).

17. Sturgess, J. M. Bronchial mucus secretion in cystic fibrosis. In: F. Falkner: Mucus Secretions and Cystic Fibrosis. Modern Problems in Paediatrics. Vol. 19, p. 129-140, (Karger, Basel) 1977.

18. Warwick, W. J. and Shapiro, B. L.: Clinical observations about a hypothetical CF factor. Cystic Fibrosis Club Abstracts, p. 91. Eighteenth Annual Meeting, San Francisco, 1977.

19. Wilson, G. B., Arnaud, P., and Fudenberg, H. H.: Improved method for detection of cystic fibrosis protein in serum using the LKB Multiphor electrofocusing apparatus. Pediatr. Res., 11: 986 (1977).

20. Wood, R. E., Boat, T. F., and Doershuk, C. F.: Cystic fibrosis. Amer. Rev. Resp. Dis., 113: 833 (1976).

21. Wood, R. E., Wanner, A., Hirsch, J. and Farrell, P. M.: Tracheal mucociliary transport in patients with cystic fibrosis and its stimulation by terbutaline. Amer. Rev. Resp. Dis., 111: 733 (1975).

22. Yeates D., Sturgess, J. M., Levison, H., Khan, S., Aspin, N.: Mucociliary tracheal transport rates in cystic fibrosis. Arch. Dis. Childhood, 51: 28 (1976).

23. This research was supported by the Canadian Cystic Fibrosis Foundation.

24. Requests for reprints should be addressed to: Dr. J. M. Sturgess, Department of Pathology, The Hospital for Sick Children, 555 University Avenue, Toronto, Ontario, Canada M5G 1 X8.

25. Received for publication February 22, 1978.

26. Accepted for publication February 22, 1978. 